\title{
Antifertility action of a sterol sulphate in the rabbit
}

\author{
P. J. Burck, A. L. Thakkar and R. E. Zimmerman \\ Biochemical and Pharmaceutical Research Departments, Lilly Research Laboratories, \\ Indianapolis, Indiana 46285, U.S.A.
}

\begin{abstract}
Summary. Introduction of $0.5 \mathrm{mg} \beta$-sitosteryl sulphate, a potent acrosin inhibitor, in $\mathrm{K}-\mathrm{Y}$ jelly into the vagina of rabbits before coitus lowered the pregnancy rate. Cholesteryl sulphate had no effect. A $1.5 \times 10 \mathrm{~mm}$ silicone rod containing $10 \%$ $(\mathrm{w} / \mathrm{w}) \beta$-sitosteryl sulphate released 1-2 $\mu \mathrm{g}$ of compound per day over a 16-day period in vitro. When such implants were placed in rabbit uteri, there was a significant reduction in the numbers of embryos in those horns.
\end{abstract}

\section{Introduction}

Acrosin (EC 3.4.21.10), the trypsin-like enzyme of spermatozoa, has been implicated as the enzyme responsible for penetration of the zona pellucida by spermatozoa (Stambaugh \& Buckley, 1969). Meizel \& Lui (1976) first suggested that acrosin also plays a role in the acrosome reaction of mammalian spermatozoa. Inhibitors of acrosin should, therefore, be useful as potential antifertility agents.

Numerous naturally occurring and synthetic acrosin inhibitors have been used in vitro and in vivo to inhibit fertilization (Zaneveld, 1976) since the original observation (Stambaugh, Brackett \& Mastroianni, 1969) that chicken ovomucoid and soybean trypsin inhibitor prevented the in-vitro fertilization of rabbit ova. The most potent synthetic acrosin inhibitors, 1-chloro-3-tosylamido-7-amino-2-heptanone (TLCK) and p-nitrophenyl- $p^{\prime}$-guanidinobenzoate $\mathrm{HCl}$ (NPGB) completely blocked fertilization in vivo in the rabbit when preincubated with spermatozoa before insemination or deposited in the vagina in $\mathrm{K}-\mathrm{Y}$ jelly before coitus (Zaneveld, Robertson \& Williams, 1970). These same inhibitors also had antifertility activity in the stumptailed macaque (Macaca arctoides) when deposited in the vagina in K-Y jelly (Zaneveld, Beyler, Kim \& Bhattacharyya, 1979).

If acrosin inhibitors are to be considered for use as contraceptive agents in man, they should not inhibit other enzymes. Neither NPGB nor TLCK meet this criterion since they are both potent inhibitors of other mammalian proteases such as trypsin and thrombin. Sterol sulphates, however, are not only very potent but are also specific acrosin inhibitors (Burck \& Zimmerman, 1980). Their contraceptive efficacy in vivo was tested in rabbits in the present study.

\section{Materials and Methods}

The pyridinium sulphates of $\beta$-sitosterol (5-cholesten-24b-ethyl-3 $\beta$-ol) and cholesterol (5cholesten-3 $\beta$-ol) were prepared under anhydrous conditions by reacting the crystalline sterols with pyridine sulphur trioxide (Sobel \& Spoerri, 1941). The sterol sulphate pyridinium salts were crystallized to a constant melting point which agreed with literature values. The homogeneity of 
the sterol sulphates was confirmed by chromatography of methanolic solutions of the compounds on silica gel plates (Bleau \& VandenHeuvel, 1974). The stability of $1 \mathrm{mg} / \mathrm{ml}$ solutions of the sterol sulphates in $\mathrm{Ca}^{2+}$-free Ringer solution $(0.9 \% \mathrm{NaCl}, 0.04 \% \mathrm{KCl}, 0.02 \%$ $\mathrm{NaHCO}_{3}, \mathrm{pH} 7.4$ ) over a 30-day period was ascertained by the same thin-layer chromatographic techniques. Sterol sulphate pyridinium salts were converted to the corresponding potassium salts (Sobel \& Spoerri, 1941) for use in the in-vivo experiments.

The effect of cholesteryl sulphate and $\beta$-sitosteryl sulphate on sperm motility was measured by diluting rabbit semen, collected using an artificial vagina, with an equal volume of $\mathrm{Ca}^{2+}$-free Ringer solution or with a $1 \mathrm{mg} / \mathrm{ml}$ solution of the appropriate sterol sulphate in $\mathrm{Ca}^{2+}$-free Ringer solution and incubating these sperm samples at $37^{\circ} \mathrm{C}$. Samples of spermatozoa were examined at various times during a $3-\mathrm{h}$ period with a phase-contrast microscope to assess their motility.

\section{Intravaginal experiments}

A solution of $1 \mathrm{mg}$ cholesteryl sulphate or $\beta$-sitosteryl sulphate $/ \mathrm{ml} \mathrm{in} \mathrm{Ca}^{2+}$-free Ringer solution was thoroughly mixed with an equal volume of K-Y jelly. One $\mathrm{ml}$ of this mixture was then inserted with a syringe into the vagina of Dutch-belted virgin rabbits weighing approximately $3 \mathrm{~kg}$. Control rabbits received $1 \mathrm{ml}$ of a mixture of equal volumes of K-Y jelly and $\mathrm{Ca}^{2+}$-free Ringer solution. The rabbits were caged in a constant-temperature room on a 14-h light/10-h dark cycle. These does were then mated with bucks of proven fertility. Human chorionic gonadotrophin (134 i.u.) was administered intravenously just after mating to ensure ovulation. The does were killed 14 days after mating. Uteri were examined for embryos, and ovaries for ovulation sites (corpora lutea).

\section{Intrauterine experiments}

$\beta$-Sitosteryl sulphate was incorporated into silicone implants at a level of $10 \%(\mathrm{w} / \mathrm{w})$ by thoroughly mixing the sterol sulphate with Dow MDX 4-4210 elastomer and Dow MDX 4-4210 curing agent (Dow Corning, Midland, Michigan). This mixture was injected into a stainless-steel block mould with a syringe and cured at $90^{\circ} \mathrm{C}$ for $1 \mathrm{~h}$. After the block had cooled, the moulded rods $(1.5 \mathrm{~mm}$ diam.) were removed and cut into $10 \mathrm{~mm}$ lengths, each weighing about $40 \mathrm{mg}$ and containing about $4 \mathrm{mg} \beta$-sitosteryl sulphate. The silicone implants were sterilized with ethylene oxide, and aseptic measures were employed for their storage and handling.

The rods were inserted into the uteri of Dutch-belted virgin female rabbits weighing approximately $3 \mathrm{~kg}$. A blank rod or a rod containing $\beta$-sitosteryl sulphate was inserted at a random point along the right uterine horn by making an incision through the uterine wall. The rod was placed in the uterine lumen, and the incision was closed by a suture attached to the proximal end of the rod. Sterile pencillin G (Duracillin: Eli Lilly, Indianapolis, Indiana), 300000 units, was administered i.m. daily for the first 4 days of the 14-day recovery period following surgery. After recovery the does were mated to bucks of proven fertility and treated as described above for the intravaginal experiments.

In-vitro release of $\beta$-sitosteryl sulphate from the silicone implants was measured by incubating the rods in $10 \mathrm{ml} \mathrm{Ca}{ }^{2+}$-free Ringer solution at $37^{\circ} \mathrm{C}$. At various times the incubation solution was changed and assayed for acrosin inhibitory activity. Acrosin activity was determined by measuring the initial rate of hydrolysis of $N$ - $\alpha$-benzoyl-DL-arginine- $p$-nitroanilide $\mathrm{HCl}$ (BAPNA) by the enzyme at $25^{\circ} \mathrm{C}$ in $0.05 \mathrm{M}$-triethanolamine, $\mathrm{pH} 7.8$, with a Gilford 240 recording spectrophotometer. A molar extinction coefficient of $9950 \mathrm{M}^{-1} \mathrm{~cm}^{-1}$ was used to determine reaction velocities. One unit of acrosin inhibitory activity reduces the substrate turnover by $1 \mu \mathrm{mol} / \mathrm{min}$. The acrosin used for these inhibition studies was derived from boar spermatozoa and had a specific activity of 14.7 units/mg using BAPNA as the substrate. The amount of $\beta$-sitosteryl sulphate released into the incubation medium was determined from a standard curve of inhibition of acrosin by the sterol sulphate. 


\section{Results}

Aqueous solutions of cholesteryl sulphate and $\beta$-sitosteryl sulphate were stable over a 30 -day period. In all cases at least $95 \%$ of the original sterol sulphate remained in solution. Any degradation observed was due to hydrolysis to the corresponding free sterols which do not inhibit acrosin (Burck \& Zimmerman, 1980).

$\beta$-Sitosteryl sulphate and cholesteryl sulphate had no effect on sperm motility as observed by standard in-vitro techniques. During the 3 -h period no difference was observed in the overall percentage of motile spermatozoa present in control suspensions when compared to sperm suspensions containing $1 \mathrm{mg}$ cholesteryl sulphate $/ \mathrm{ml}$ or $1 \mathrm{mg} \beta$-sitosteryl sulphate $/ \mathrm{ml}$.

Intravaginal experiments. Cholesteryl sulphate had no significant intravaginal antifertility effect when compared to the K-Y jelly controls (Table 1). $\beta$-Sitosteryl sulphate did lower the pregnancy rate but did not significantly reduce the number of embryos produced per pregnant animal. Neither compound had any effect on ovulation as determined by comparison of corpora lutea in treated and control animals.

Table 1. The intravaginal antifertility activity of sterol sulphates in rabbits

\begin{tabular}{|c|c|c|c|c|c|}
\hline Treatment & $\begin{array}{l}\text { No. of } \\
\text { rabbits }\end{array}$ & $\begin{array}{l}\text { No. of pregnant } \\
\text { rabbits }\end{array}$ & $\begin{array}{l}\text { Total no. of } \\
\text { embryos }\end{array}$ & $\begin{array}{l}\text { Total no. of } \\
\text { corpora lutea }\end{array}$ & $\begin{array}{c}\text { Mean } \pm \text { s.d. no. of } \\
\text { embryos/pregnant } \\
\text { rabbit }\end{array}$ \\
\hline K-Y Jelly & 6 & 6 & 35 & 41 & $5.8 \pm 1.5$ \\
\hline Cholesteryl sulphate & 8 & 6 & 32 & 55 & $5 \cdot 3 \pm 1 \cdot 5$ \\
\hline$\beta$-Sitosteryl sulphate & 6 & $3^{*}$ & $11^{*}$ & 40 & $3.7 \pm 0.6$ \\
\hline
\end{tabular}

* Significantly different from the value of K-Y jelly treatment $(P<0.05)$ using Student's $t$ test.

Intrauterine experiments. The cumulative release of $\beta$-sitosteryl sulphate from a $40 \mathrm{mg}$ silicone rod in vitro was $1 \cdot 0,6 \cdot 0,23 \cdot 1$ and $25 \cdot 3 \mu \mathrm{g}$ on Days $1,4,14$ and 16 respectively. The presence of active acrosin inhibitor released into $\mathrm{Ca}^{2+}$-free Ringer solution was assayed to be certain that the sterol sulphate was being released in an active form. The release of $\beta$-sitosteryl sulphate from the silicone matrix was very low $(\sim 0.6 \%$ released), but quite constant $(1-1.7$ $\mu \mathrm{g} / \mathrm{day}$ ) over the 16-day period. No acrosin inhibitory activity was released from blank silicone rods. The amount of $\beta$-sitosteryl sulphate remaining in the silicone rods after insertion into the uterus was not checked in these experiments.

The efficacy of $\beta$-sitosteryl sulphate as an intrauterine contraceptive is summarized in Table 2. Blank rods had no significant contraceptive effect: implanted embryos were found on both sides of the blank rod. The treatments had no effect on ovulation.

Table 2. The intrauterine antifertility activity of $\beta$-sitosteryl sulphate in rabbits

\begin{tabular}{llcccc}
\hline \multicolumn{1}{c}{ Treatment } & Horn & $\begin{array}{c}\text { No. of } \\
\text { uterine horns }\end{array}$ & $\begin{array}{c}\text { No. of } \\
\text { embryos }\end{array}$ & $\begin{array}{c}\text { No. of corpora } \\
\text { lutea }\end{array}$ & $\begin{array}{c}\text { Mean } \pm \text { s.d. no. } \\
\text { of embryos }\end{array}$ \\
\hline Blank rod & Treated & 10 & 19 & 27 & $1.9 \pm 1.5$ \\
& Contralateral & 10 & 22 & 26 & $2 \cdot 2 \pm 1 \cdot 0$ \\
B-Sitosteryl sulphate rod & Treated & 10 & 3 & 28 & $0 \cdot 3 \pm 0 \cdot 5^{*}$ \\
& Contralateral & 10 & 26 & 31 & $2 \cdot 6 \pm 0.7$ \\
\hline
\end{tabular}

* Significantly different from the value for the blank rod-treated horns $(P<0.001)$ using Student's $t$ test. 


\section{Discussion}

Our primary objective in these experiments was to evaluate the contraceptive activity of sterol sulphates. Intravaginal or intrauterine administration of these potent acrosin inhibitors should inhibit the physiological events reported to be mediated by acrosin such as activation of proacrosin, the acrosome reaction, and the penetration of the zona pellucida by spermatozoa. Inhibition of any of these events by a sterol sulphate should result in contraception. Our experiments with intravaginal application of cholesteryl sulphate and $\beta$-sitosteryl sulphate indicate that at the dose used $(0.5 \mathrm{mg})$ only $\beta$-sitosteryl sulphate lowered the pregnancy rate. It is possible that at higher doses, similar to those used by others for TLCK and NPGB, a more complete contraceptive effect might have been observed for both sterol sulphates. It is also possible that the sterol sulphatase present in the female reproductive tract more readily hydrolyses the naturally occurring cholesteryl sulphate, rendering it inactive.

Intrauterine administration should achieve an antifertility effect with much lower levels of compound because the total number of spermatozoa in the uterus is much lower than that deposited in the vagina, and the delivery of the acrosin inhibitor is much nearer the site of acrosin-mediated events in the reproductive tract. The contraceptive effect of chlormadinone acetate and progesterone released from intrauterine silicone devices has been tested in the rabbit (Vickery, Erickson, Bennett, Mueller \& Haleblian, 1970).

In these experiments with $\beta$-sitosteryl sulphate an intrauterine silicone rubber device was used. The devices released microgram quantities of $\beta$-sitosteryl sulphate in vitro, and the compound released inhibited acrosin in vitro. Similar implants in rabbit uteri had a significant antifertility effect, presumably due to the release of $\beta$-sitosteryl sulphate from the silicone rod. These compounds therefore warrant further study as potential contraceptives for human use.

\section{References}

Bleau, G. \& VandenHeuvel, W.J.A. (1974) Desmosteryl sulphate and demosterol in hamster epididymal spermatozoa. Steroids 24, 549-556.

Burck, P.J. \& Zimmerman, R.E. (1980) The inhibition of acrosin by sterol sulphates. J. Reprod. Fert. 58, 121-125.

Meizel, S. \& Lui, C.W. (1976) Evidence for the role of trypsin-like enzyme in the hamster sperm acrosome reaction. J. exp. Zool. 195, 137-144.

Sobel, A.E. \& Spoerri, P.E. (1941) Steryl sulfates. I. Preparation and properties. J. Am. Chem. Soc. 63, 1259-1261.

Stambaugh, R. \& Buckley, J. (1969) Identification and subcellular localization of the enzymes effecting penetration of the zona pellucida by rabbit sperm atozoa. J. Reprod. Fert. 19, 423-432.

Stambaugh, R., Brackett, B.G. \& Mastroianni, L. (1969) Inhibition of in vitro fertilization of rabbit ova by trypsin inhibitors. Biol. Reprod. 1, 223-227.
Vickery, B.H., Erickson, G.I., Bennett, J.P., Mueller, N.S. \& Haleblian, J.K. (1970) Antifertility effects in the rabbit by continuous low release of progestin from an intrauterine device. Biol. Reprod. 3, 154162.

Zaneveld, L.J.D. (1976) Sperm enzyme inhibitors as antifertility agents. In Human Semen and Fertility Regulation in Men, pp. 570-582. Ed. E. S. E. Hafez. C. V. Mosby, St Louis.

Zaneveld, L.J.D., Robertson, R.T. \& Williams, W.L. (1970) Synthetic enzyme inhibitors as antifertility agents. FEBS Letters $11,345-347$.

Zaneveld, L.J.D., Beyler, S.A., Kim, D.S. \& Bhattacharyya, A.K. (1979) Acrosin inhibitors as vaginal contraceptives in the primate and their acute toxicity. Biol. Reprod. 20, 1045-1054.

Received 30 October 1981 